\title{
Factors Affecting Customer Loyalty of Islamic Bank in Sumbawa City, Indonesia
}

\author{
Rizka Alwathan ${ }^{1}$, Peni Nugraheni'* \\ ${ }^{1,2}$ Universitas Muhammadiyah Yogyakarta
}

Submitted: 24 May, 2021; Accepted: 16 January, 2022; Published: 21 January, 2022

\begin{abstract}
This study aims to examine the factors affecting customer loyalty in Sumbawa city, Nusa Tenggara Barat province, Indonesia. This province become the driving factor of the Islamic bank market because it is dominated by $97 \%$ Muslims. Meanwhile, the independent factors include profit sharing, service quality, transparency, and trust. Data were collected using a questionnaire and analyzed using multiple regression methods. The results showed that service quality, transparency, and trust positively affect the customer loyalty of Islamic bank, while profit sharing have no influence. Furthermore, Muslim financial institutions are expected to use their best performance to increase customer loyalty. The practitioners and regulators can improve their performance and develop the Islamic financial industry by considering the result above.
\end{abstract}

Keywords: customer loyalty, profit sharing, service quality, transparency, trust 


\section{INTRODUCTION}

The bank is one of the financial institutions that have an important role in people's economic activities because it serves as an intermediary between parties with a surplus of funds (Khairi, Nursalim, \& Parno, 2018). In Indonesia, Islamic banks give the option to society to either save or finance. Therefore, this financial institution needs to have a good future because the majority of the people living in the country are dominated by Muslims.

According to Suhartanto, Gan, Sarah, and Setiawan (2019) also Ganiyu, Uche, and Elizabeth (2012), the sustainability of the financial service industry is determined by consumers' loyalty to supports the continuity of an organization to compete with others. Therefore, Islamic banks always find it difficult to maintain the existence of customers. Previous studies showed that consumer loyalty is affected by profit sharing, service quality, transparency, and trust (Khairi, Nursalim, \& Parno, 2018; Suhartanto et al., 2019; Wahyoedi, 2017).

The profit-sharing system becomes the customer's intention while choosing Islamic banks because the transacting parties have a role as partners than being debtors and creditors (Islam \& Rahman, 2017). Meanwhile, the service quality serves as a service provider in the banking sector (Christanti, Wulandari, Narmaditya, \& Utomo, 2017). According to Suhartanto et al. (2019), it helps to strengthen customers' satisfaction. Also, the study of Yuliafitri and Khoiriyah (2016) and Wahyoedi (2017) showed that transparency is a situation where an organization provides the information needed by stakeholders, while trust indicates the consumer's belief to receive products and services.

Khairi et al. (2018) indicated that profit-sharing positively affects the customer's loyalty to an Islamic bank. Meanwhile, Khotimah (2018) failed to indicate the relationship between the profit-sharing system and consumer loyalty. According to Ltifi, Hikkerova, Aliouat, and Gharbi (2016), service quality and trust positively affect the selection of Islamic banks in Tunisia. The study of Wahyoedi (2017) showed that those variables positively influence customer loyalty in Indonesia. According to Sari and Marlien (2019), service quality failed to affect customer loyalty.

Considering the previous studies, this study aims to examine the factors that influence customer loyalty in Sumbawa city, province of Nusa Tenggara Barat, Indonesia. Several reasons for taking the object in NTB (KNKS, 2020) include: first, the majority of the Muslim population in NTB and Sumbawa reaches $97 \%$ and $96.45 \%$ respectively. This indicates that the potential for developing Islamic finance is large. Second, the 2019 national survey showed NTB to become an economic barometer occupying the third position in literacy and sixth in inclusion index with $22.05 \%$ and $16.27 \%$ respectively. Meanwhile, in 2016, it only achieved $5.1 \%$ and $8.4 \%$ for the two indexes.

The NTB province become the driving factor of the Islamic bank market because $97 \%$ of its population is dominated by Muslims. However, the September 2021 data of the Financial Service Authority (OJK) showed that the third-party fund (TPF) has a lower percentage compared to conventional banks. Figure 1 below shows the comparison. 


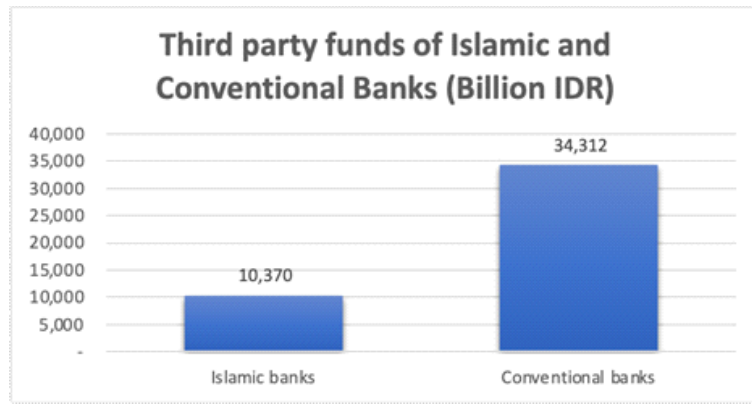

Source: OJK (2021)

Figure 1. TPF percentage of Islamic and Conventional Banks

Figure 1 describes that the TPF for conventional and Islamic banks was 34,312 billion IDR and 10,370 billion IDR respectively. Therefore, the Islamic banks market is wide in NTB because it is supported by a large number of Muslims and the regional governance.

Previous studies showed that cultural differences affect consumer loyalty (Fianto, Gan, Widiastuti, \& Sukmana, 2020). According to Rahman, Zakaria, Ibrahim, Azam, and Musa (2020), the high demand for products and services help to create long-term relationships between Islamic banks and their customers.

The existence of this financial institution tends to be a choice because it provides opportunities for people to apply Muslim values in their daily lives (Nugraheni \& Widyani, 2020). Economic inequality is one of the societal problems that is expected of Islamic banks to overcome because they prioritize justice in each aspect. These financial institutions conduct their activities and profit-sharing differently (Wahyoedi, 2017; Asnawi, Sukoco, \& Fanani, 2019).

Furthermore, Islamic bank needs support from stakeholders including customers to maintain the continuity of their activities. The market share of this financial institution is influenced by a total number of consumer and third-party funds. Therefore, customers use saving and deposit products to increase third-party funds(Hanafi, 2021).

The study of Suhartanto et al. (2019) showed that consumer loyalty is the willingness to buy or use the same service and product in the future. According to Ganiyu et al. (2012), this loyalty is important for a business entity because it positively influences customers to (1) continue buying or using organization products and services, (2) promote the products to other parties, and (3) buy or use other products provided by the company. The study of Islam and Rahman (2017) showed that loyalty arises while consumers are satisfied with the products and services provided by banks. Therefore, customers do not only consider halal products but also the profit-sharing ratio (Nasim, Murniasih, Heryana, \& Purnomo, 2020). According to Supriyanto, Wiyono, and Burhanuddin (2021), non-financial performance factors including trust and excellent service quality affect customer loyalty. 
Consumer loyalty tends to promote good financial performance in the form of greater profits (Fianto et al., 2020). Therefore, Islamic banks need to know how sharia principles are used in disseminating information about the products and services offered(Islam \& Rahman, 2017). These experiences enable the consumers to reuse banking products and services in the future.

This study is expected to contribute to the identification of factors influencing customer loyalty in a specific region. Therefore, practitioners and regulators need to continue to improve their performance and develop Islamic financial organizations because these factors are affected by societal culture.

\section{Hypothesis Development}

\section{The Influence of Profit-Sharing on Customers Loyalty of Islamic Bank}

Profit-sharing is a system in which two parties agree to conduct business activities and divide the profit earned based on the pre-agreed ratio (Ahmadi, 2019). Also, it is a special characteristic that attracts consumers especially Muslims in conducting financial transactions. According to Asnawi et al. (2019), the profit-sharing system is one of the drivers of consumer loyalty to Islamic banks. Meanwhile, the transaction without interest rate is to convince customers that Muslim financial institutions have sharia compliance.

Customers that are satisfied with the profit-sharing system tend to continuously use the banking products and services and even advise others to use them. Khairi et al. (2018) showed that profit-sharing positively affects customers' loyalty to an Islamic bank. Therefore, the first hypothesis is proposed as follows:

H1: Profit-sharing positively affects customers' loyalty to Islamic banks.

\section{The Influence of Service Quality on Customers Loyalty of Islamic Bank}

Service quality is one of the factors that consumers consider in choosing financial services. According to Christanti, Wulandari, Narmaditya, and Utomo (2017), it is an important aspect of the banking sector. Also, service quality is a specific dimension to improve the Muslim financial institution performance in Indonesia (Asnawi et al., 2019).

Service quality is an action taken by the bank to meet the consumers' desires (Asnawi et al., 2019). According to Suhartanto et al. (2019), customers tend to continue their relationship with the financial institution while feeling high service quality. Therefore, good service quality creates and builds customer loyalty because it enables them to continue their commitment in the future. Asnawi et al. (2019) explained that there is a positive relationship between service quality and customer loyalty of Islamic banks in Indonesia. Therefore, the second hypothesis is proposed as follows:

$\mathrm{H} 2$ : Service quality positively affects customers' loyalty to Islamic banks. 


\section{The Influence of Transparency on Customers Loyalty of Islamic Bank}

Transparency is one of the components in corporate governance that shows the available information needed by consumers (Nugraheni \& Fauziah, 2019). According to ElJunusi (2012), it is openness in presenting material and relevant information, as well as the decision-making process. Meanwhile, some people still have little knowledge about Islamic banks despite the disclosure of financial and non-financial information that increases public trust.

Customers tend to have different reasons for saving their money in Islamic banks. According to Suhartanto et al. (2019), consumers loyalty is affected by emotional and religious drive. The study of Shome, Jabeen, and Rajaguru (2018) indicated other factors including profit/loss, economic, and social development, or peer group influence the selection of Islamic banks. Meanwhile, the information disclosed by Muslim financial institutions is expected to fulfill consumers' needs. According to Yuliafitri and Khoiriyah (2016), transparency helps to provide clear, relevant, and timely information on the financial and non-financial aspects. Therefore, the ease of access and the provision of clear information reassure customers to believe that Islamic banks perform their activities due to sharia compliance.

Easy access to information affect consumers' loyalty because it increases their confidence. El-Junusi (2012) explained that transparency influence the societal reputation and trust of Islamic banks. Also, the study of Yuliafitri and Khoiriyah (2016) showed that transparency positively affects muzakki loyalty in zakah organizations. Based on the above explanation, the third hypothesis proposed is as follows:

H3: Transparency positively affects customers' loyalty to Islamic banks.

\section{The Influence of Trust on Customers Loyalty of Islamic Bank}

Trust is the consumer's belief in getting what they want from providers of goods and services (Sari \& Marlien, 2019). Also, trust is the determining factor because it enables customers to be confident in using products or services of Islamic banks (Wahyoedi, 2017). According to Asnawi et al. (2019), trust tends to arise while there is sharia compliance, no usury, and profit-sharing for Muslim financial institutions. Furthermore, high trust encourages consumers to always conduct transactions because it increases great loyalty to Islamic banks. The study of Amron, Usman, and Mursid (2017) showed that trust positively affects the decision to use the product at IFIs in Indonesia.

Wahyoedi (2017) indicated that trust positively affects consumer loyalty to Islamic banks. The consumer's trust and potential are important to develop the Muslim financial institution market(Nugraheni \& Fauziah, 2019). Therefore, the fourth hypothesis proposed is as follows:

H4: Trust positively affects customers' loyalty to Islamic banks. 


\section{METHOD}

A total of 100 Islamic banks customers in Sumbawa city, NTB Province, Indonesia were selected as participants for this study. According to the KNKS (2020), this country's provinces have the potential to develop natural and human resources which are strengthened by local wisdom and customs.

This study used the purposive sampling method to determine the respondents' criteria as follows: (1) customers above 18 years old and (2) customers of Islamic banks that deposit or save and have the account for more than 1 year.

Data were collected through questionnaires that are self-developed using 5 Likertscale from strongly agree to strongly disagree. Meanwhile, the dependent variable is customer loyalty, while the independent variables are profit sharing, service quality, transparency, and trust. Data were analyzed using the validity and reliability, as well as multiple regression tests consisting of coefficient determination, F-test, and t-test. Picture 2 below shows the model of this study.

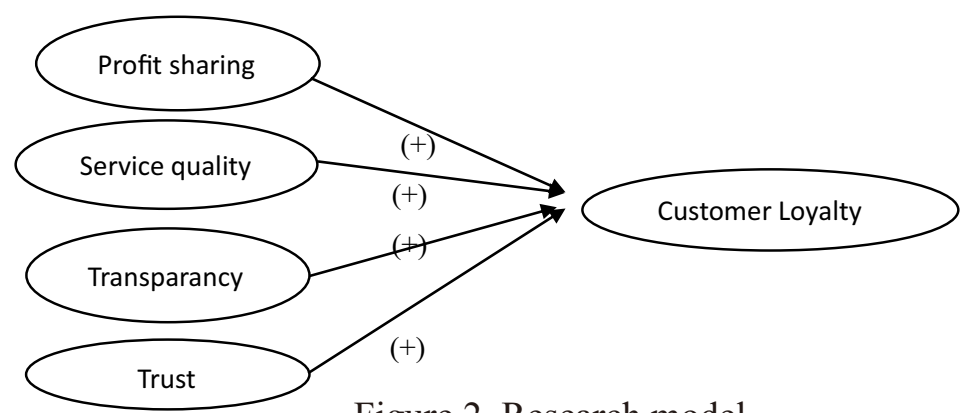

Figure 2. Research model

\section{RESULT AND DISCUSSION}

A total of 138 questionnaires are directly distributed to consumers that have made transactions at Bank Syariah Mandiri but only 100 or $72.46 \%$ were processed. In terms of gender, a total of 62 and 38 respondents were female and male respectively. A total of 5, 12, 17, 44 , and 22 people were less than 20, between 20-25, between 26-35, between 36-55, and above 45 years old respectively. In terms of education, a total of 61, 12, 22, and 5 are undergraduate, high school students, diploma, and postgraduate respectively. Based on occupation type, a total of 31 or $31 \%$ of respondents are civil servants.

The validity test showed that all variables are valid if the significant value is more than 0.05 . Meanwhile, the reliability test is used to calculate the consistency and accuracy of the questions. A variable is reliable if it has a Cronbach Alpha $>0.6$. The results showed that all variables are reliable because the Cronbach alpha value is more than 0.6. 
Table 1. Multiple regression results

\begin{tabular}{lcccc}
\hline \multicolumn{1}{c}{ Variables } & $\begin{array}{c}\text { Coefficient } \\
\text { B }\end{array}$ & $\begin{array}{c}\text { Std. } \\
\text { Error }\end{array}$ & t-value & Sig. \\
\hline (Constant) & -1.17 & 2.366 & -0.495 & 0.622 \\
Profit-sharing & 0.137 & 0.1 & 1.37 & 0.174 \\
service quality & 0.395 & 0.142 & 2.784 & 0.006 \\
transparency & 0.272 & 0.125 & 2.187 & 0.031 \\
trust & 0.208 & 0.084 & 2.463 & 0.016 \\
& & & & \\
R Square & 0.444 & F_statistic & 18.997 \\
Adj. R Square & 0.421 & Prob. (F_statistics) & 0.000 \\
\hline
\end{tabular}

Table 1 shows the multiple regression analysis including the coefficient determination, F-test, and t-test. Meanwhile, the coefficient of determination is used to measure the rate at which the independent variable influences the dependent one. The coefficient of determination value has an Adjusted $\mathrm{R}^{2}$ of $42.1 \%$ and the remaining $57.9 \%$ is explained by other factors outside this study. Therefore, profit sharing, service quality, transparency, and trust affect customer loyalty of Islamic banks simultaneously because the F-test value is $0.000<0.05$. The partial test result is explained below.

The $\mathrm{H} 1$ is rejected because the profit-sharing value shows a regression coefficient of 0.137 with a significant value of $0.174>0.05$. This means that profit-sharing failed to significantly affect the customers' loyalty to an Islamic bank. The H2 is accepted because the service quality variable shows a regression coefficient of 0.395 with a significant value of 0.006 $<0.05$. This means that service quality positively affects the customers' loyalty to an Islamic bank. The H3 is accepted because transparency shows a regression coefficient of 0.272 with a significant value of $0.031<0.05$. This means that transparency positively affects the customers' loyalty to an Islamic bank. The H4 is accepted because the trust variable shows a regression coefficient of 0.208 with a significant probability value of $0.016<0.05$. This means that trust positively affects the customers' loyalty to an Islamic bank.

Profit-sharing failed to influence customers' loyalty because $\mathrm{H} 1$ is rejected. The result is in line with Khotimah (2018) that profit-sharing does not affect customers' loyalty. Meanwhile, Islamic Bank in NTB province was established to meet the expectations of the Muslim community as the major population. This financial institution also encourages them to save without considering the amount of profit-sharing because the transaction is based on sharia principles. According to Rahman et al. (2020), the existence of Islamic banks positively affects the development of the financial industry. 
Service quality positively affects the customers' loyalty to Islamic banks because $\mathrm{H} 2$ is accepted. The result supports the study of Wahyoedi (2017) and Asnawi et al. (2019) that Service quality influences the consumer's loyalty. This means that good quality service tends to meet the customer's expectations. The existence of Islamic banks creates and builds loyalty because it allows customers to feel comfortable and continue using the institution's products in the future.

Transparency positively affects the customers' loyalty to Islamic banks because H3 is accepted. This result is in line with the study of Yuliafitri and Khoiriyah (2016). According to Kim and Kim (2016), transparency encourages a positive relationship between an organization and customers.

The statistical result showed that trust positively affects the customers' loyalty to Islamic banks because H4 is accepted. This is in line with the study of Wahyoedi (2017) and Khotimah (2018). Therefore, trust plays an important role in increasing the good performance of the bank, provision of services, and the integrity in providing consistent service to ultimately form customer loyalty.

\section{CONCLUSION}

This study aims to examine the factors that influence the customer loyalty of Islamic banks in Sumbawa city, Province of Nusa Tenggara Barat, Indonesia. The results showed that profit-sharing has no effect while service quality, transparency, and trust positively affect the customers' loyalty.

These results are in line with previous studies that the independent variables influence customer loyalty of Islamic banks. This study has several implications including: first, it explains that consumer loyalty is affected through Islamic banks' performance at the financial and non-financial aspects. Islamic banks still have to maintain financial performance despite the analysis results indicating no significant relationship between profit sharing and customer loyalty. Second, this study is expected to improve banking management and provide products and services because customer loyalty supports an organization's survival in the future. Furthermore, the understanding of consumer characteristics in the areas where Islamic banks operate helps these institutions to provide required services.

Several limitations in this study include: first, data were collected using a questionnaire thereby depending on the respondents' perception. Further study needs to use interviews to increase customers' understanding of the factors that influence their loyalty. Second, the analysis result is not generalized because it was only conducted in Sumbawa, Nusa Tenggara Barat province, Indonesia. 


\section{BIBLIOGRAPHY}

Ahmadi. (2019). The Effect of Perception and Profit Sharing on the Decision to Become a Customer at Bank BNI Syariah Merangin Regency. Dinasti International Journal of Management Science, 1(1), 1-11.https://doi.org/10.31933/DIJMS.

Amron, A., Usman, U., \& Mursid, A. (2017). Buying Decision in the Marketing of Sharia Life Insurance (Evidence From Indonesia). Journal of Islamic Marketing, 9(2), 370-383.

Asnawi, N., Sukoco, B. M., \& Fanani, M. A. (2019). The Role of Service Quality within Indonesian Customers Satisfaction and Loyalty and its Impact on Islamic Banks. Journal of Islamic Marketing, 11(1), 192-212. https://doi.org/10.1108/JIMA-032017-0033.

Christanti, E. H., Wulandari, D., Narmaditya, B. S., \& Utomo, S. H. (2017). Factors Influencing Customers in Using Islamic Banking Service. In The 3rd International Conference on Economics, Business and Accounting Studies (pp. 260-268). Faculty of Economics and Business - Universitas Jember, Indonesia.

El-Junusi, R. (2012). Implementasi Shariah Governance Serta Implikasinya Terhadap Reputasi dan Kepercayaan Bank Syariah. Al-Tahrir, 12(1), 91-115.

Fianto, B. A., Gan, C., Widiastuti, T., \& Sukmana, R. (2020). Customer Loyalty to Islamic Banks: Evidence from Indonesia. Cogent Business \& Management, 7(1), 1859849. https://doi.org/10.1080/23311975.2020.1859849.

Ganiyu, R. A., Uche, I. I., \& Elizabeth, A. O. (2012). Is Customer Satisfaction an Indicator of Customer Loyalty? Australian Journal of Business and Management Research, 2(07), 14-20.

Hanafi, S. M. (2021). Determinant of Market Share in the Indonesian Islamic Banking Industry. Muqtasid: Jurnal Ekonomi dan Perbankan Syariah,12(1), 1-16. https://doi.org/ 10.18326/muqtasid.v12i1.1-16.

Islam, J. U., \& Rahman, Z. (2017). Awareness and Willingness towards Islamic Banking among Muslims: An Indian Perspective. International Journal of Islamic and Middle Eastern Finance and Management, 10(1), 92-101. https://doi.org/10.1108/IMEFM01-2016-0017.

Khairi, Nursalim, E., \& Parno. (2018). Pengaruh Pendapatan Bagi Hasil dan Pemberian Bonus terhadap Loyalitas Nasabah di Bank Syariah Mandiri Kantor Cabang Sangatta. International Journal Ihya' Ulum Al-Din, 20(1), 17-40.

Khotimah, N. (2018). Pengaruh Religiusitas, Kepercayaan, Citra Perusahaan, dan Sistem Bagi Hasil terhadap Minat Nasabah Menabung dan Loyalitas di Bank Syariah Mandiri (Studi Kasus pada Nasabah Bank Syariah Mandiri Gresik). Jurnal Ilmu Ekonomi \& Manajemen, 05(01), 37-48.

Kim, S. B., \& Kim, D. Y. (2016). The Impacts of Corporate Social Responsibility, Service Quality, and Transparency on Relationship Quality and Customer Loyalty in the Hotel Industry. Asian Journal of Sustainability and Social Responsibility, 1(1), 39-55. https://doi.org/10.1186/s41180-016-0004-1. 
KNKS. (2020). Laporan Perkembangan Ekonomi Syariah Daerah 2019-2020. Retrieved from https://knks.go.id/storage/upload/1608112995-Laporan Ekonomi Syariah Daerah 2019-2020.pdf.

Ltifi, M., Hikkerova, L., Aliouat, B., \& Gharbi, J. (2016). The Determinants of the Choice of Islamic Banks in Tunisia. International Journal of Bank Marketing, 34(5), 710-730. https://doi.org/10.1108/IJBM-11-2014-0170.

Nasim, A., Murniasih, L., Heryana, T., \& Purnomo, B. S. (2020). Islamicity Performance Index: Does It Affect the Loyalty of Islamic Bank Customers? PalArch's Journal of Archaeology of Egypt/Egyptology, 17(7), 4433-4444.

Nugraheni, P., \& Fauziah, L. (2019). The Impact of Corporate Governance on Customer Satisfaction and Loyalty of Islamic Insurance Company in Indonesia. Journal of Accounting and Investment, 20(2), 114-128. https://doi.org/10.18196/jai.2002120.

Nugraheni, P., \& Widyani, F. N. (2020). A Study of Intention to Save in Islamic Banks: the Perspective of Muslim Students. Journal of Islamic Marketing, ahead of $p$ (ahead of print). https://doi.org/10.1108/JIMA-11-2019-0233.

OJK (2021). Statistik Perbankan Syariah. Otoritas Jasa Keuangan. Retrieved from https:// www.ojk.go.id.

Rahman, F. L., Zakaria, W. M. F. W., Ibrahim, W. M. F. W., Azam, S. K. T., \& Musa, M. H. (2020). Factors Influencing Customers Loyalty towards Islamic Banking: A Case Study in Gombak, Selangor. Jurnal Intelek, 15(1), 11-20. https://doi.org/10.24191/ ji.v15i1.263.

Sari, D. C., \& Marlien, R. A. (2019). Pengaruh Kualitas Layanan, Kepercayaan dan Nilai Pelanggan terhadap Loyalitas Pelanggan (Studi pada Nasabah Tabungan Bank BNI Syariah Cabang Semarang). In Proceeding SENDI_U(pp.497-501). Unisbank.

Shome, A., Jabeen, F., \& Rajaguru, R. (2018). What Drives Consumer Choice of Islamic Banking Services in the United Arab Emirates ? International Journal of Islamic and Middle Eastern Finance and Management, 11(1),79-95. https://doi.org/10.1108/ IMEFM-03-2017-0066.

Suhartanto, D., Gan, C., Sarah, I. S., \& Setiawan, S. (2019). Loyalty towards Islamic Banking: Service Quality, Emotional or Religious Driven? Journal of Islamic Marketing, 11(1), 66-88. https://doi.org/10.1108/JIMA-01-2018-0007.

Supriyanto, A., Wiyono, B. B., \& Burhanuddin, B. (2021). Effects of Service Quality and Customer Satisfaction on Loyalty of Bank Customers. Cogent Business and Management, 8(1), 1-17.https://doi.org/10.1080/23311975.2021.1937847.

Wahyoedi, S. (2017). The Effect of Religiosity, Service Quality, and Trust on Customer Loyalty in Islamic Banking in Bogor Indonesia. International Review of Management and Business Research, 6(1), 331-340.

Yuliafitri, I., \& Khoiriyah, A. N. (2016). Pengaruh Kepuasan Muzakki, Transparansi dan Akuntabilitas pada Lembaga Amil Zakat terhadap Loyalitas Muzakki (Studi Persepsi pada LAZ Rumah Zakat). Islamiconomic, 7(2), 205-218. https://doi.org/10.32678/. 